\title{
Analysis of factors affecting stock prices in mining sector: Evidence from Indonesia Stock Ex- change
}

\author{
Zakia Maulida Antono ${ }^{a^{*}}$, Adam Amril Jaharadak ${ }^{a}$ and Abdul Ali Khatibi ${ }^{a}$
}

${ }^{a}$ Post Graduate Centre, Management and Science University, University Drive, Off Persiaran Olahraga, Section 13, 40100, Selangor, Malaysia

\begin{tabular}{l}
\hline C H R O N I C L E \\
\hline Article history: \\
Received: April 16, 2019 \\
Received in revised format: April \\
282019 \\
Accepted: May 16, 2019 \\
Available online: \\
May 17, 2019 \\
\hline Keywords: \\
Stock Price \\
Price to Earnings Ratio (PER) \\
World Oil Price \\
Inflation \\
Exchange Rate \\
Mining Sector Companies \\
\hline
\end{tabular}

\section{A B S T R A C T}

The stock prices of mining companies are affected by several factors, such as world oil price, inflation, exchange rate, and Price to Earnings Ratio (PER), political affairs, basic metal prices, etc. The objective of this study is to analyze the effects of some factors influencing the stock prices of the mining companies including Price to Earnings Ratio (PER), world oil price, inflation, and exchange rate. Secondary data from Annual Reports of Indonesia Stock Exchange (IDX), Energy Information Administration (EIA), and Bank Indonesia are used as the sources of data analysis. 35 mining companies are selected as samples from four mining sub-sectors; namely coal, oil \& gas, other metal \& mineral, and rock. The results are analyzed by using panel data regression analysis model through applying EVIEWS 10. The results indicate that Price to Earnings Ratio (PER) and world oil price had positive and significant effects on stock price. Moreover, inflation has negative and significant effect on the stock price while exchange rate has no significant effect on stock price.

C 2019 by the authors; licensee Growing Science, Canada

\section{Introduction}

Since the financial crisis experienced by Indonesian economy in 1998 and the world economic crisis by the United States in 2008, several studies have been conducted to discuss the factors for the development of the economy to remain stable and continue to grow (Pertiwi et al., 2019). The global financial crisis has a direct impact on the Indonesian economy, which is also reflected on the Indonesian stock market. The economic progress of the country can be seen on the existing capital market activity of the country. Capital markets play an important role for the development of the country's economy that encourages capital formation and sustains economic growth (Indonesian Investment Coordinating Board, 2018). Based on the stock price of the mining index listed in Indonesia Stock Exchange (IDX), the mining sector experienced a significant decrease in stock prices for four consecutive years since 2013 (Indonesia Stock Exchange, 2018) influenced primarily by several factors, such as World Oil Prices, Exchange Rate, Inflation, and internal factors. 
According to Ahmed and Giafri (2015) "the investment has an important role in economic development for both developed nations and emerging economies". The development of efficient capital markets will further enhance the confidence of domestic and foreign investors in investing in the capital market. The level of investment in the mining sector was low during the period 2013-2017 and the percentage for foreign investors is presently around 14\% compared with neighboring countries such as Thailand, Malaysia, and Vietnam which reached a percentage of $20 \%$. Even India can achieve international investment growth of up to $50 \%$ in one year (Indonesian Investment Coordinating Board, 2018). Indonesia is still far behind in terms of investment. If investment in the mining sector from year to year does not show growth, it will affect economic growth in Indonesia. That condition is because the capital market activity is one of the indicators for measuring the development of a country.

Based on the report of IDX monthly statistics, Energy Information Administration, and Bank of Indonesia (2018), there was a decline in world oil price from 2013 to 2015. In the same period, the stock price has also decreased. This phenomenon means that there is a positive effect between world oil prices and the stock price. From 2013 to 2016, the inflation has decreased and in the same period the stock price was decreased too. Its means that there is a positive influence between inflation and stock price. The Rupiah exchange rate in 2013 to 2015 was depressed. The depressed of Rupiah was followed by a decrease in the stock price. That means there is an effect between exchange rate and stock price.

Based on Sari and Wijayanto (2015), stock prices influence on investment interest because the company value is reflected in the stock price. An increase in stock prices will have an impact on increasing investors' interest in investment. Enhancement in the number of investors is possible to encourage mining companies to make exploration. Public investment will encourage the growth of a country's economy so that the government would not need to increase the country's debt if public investment awareness were high. Therefore, this research is intended to find out factors that affect stock prices in the mining sector in order to increase awareness of investment to increase the growth of the Indonesian economy in the future. Moreover, the main objective of this research is to analyze the factors (Price to Earnings Ratio, world oil price, inflation, and exchange rate) that affect stock prices of mining sector companies listed in IDX for the period 2013-2017. The research was guided by research questions as follows:

RQ1: How does Price to Earnings Ratio (PER) influence stock prices of mining sector companies listed in IDX?

RQ2: What is the significant effect of world oil price on stock prices of mining sector companies listed in IDX?

RQ3: How does Inflation influence stock prices of mining sector companies listed in IDX?

RQ4: What is the significant effect of exchange rate on stock prices of mining sector companies listed in IDX?

\section{Literature Review}

\subsection{The Capital Market}

The capital market refers to markets for medium to long term financial assets. One of the measurement tools of the growth and development country is the development of capital market and securities' industry. There are ten public sector companies listed in the Indonesia Stock Exchange. The sectors are (1) Agriculture, forestry and fishery, (2) Mining and quarrying, (3) Basic and chemical industries, (4) Various industries, (5) Consumer goods industries, (6) Property, real estate and construction activities, (7) Infrastructure, utilities, and transportation, (8) Finance, (9) Trade, services, and investment, and (10) Manufacturing (Indonesia Stock Exchange, 2018).

\subsection{Mining Sector}

Based on Law Number 4 of 2009, "mining is a part or all phases of activities in the framework of mineral or coal research, management, and exploitation including general investigation, exploration, feasibility studies, construction, mining, processing and refining, transportation and sales, and post-mining activities". This definition means mining activities whose scope can be carried out before mining, the mining process, and after mining. The mining sector has 4 sub-sectors including the coal mining sub-sector, the 
oil \& gas mining sub-sector, other metal and mineral mining sub-sectors, and the rock mining sub-sector (Indonesia Stock Exchange, 2018).

\subsection{Signaling Theory}

Signaling theory is a theory that analyzes the rise and fall of stock prices in the market, which will affect the influence of investor decisions (Fahmi, 2015). Investor's response to the signal greatly influences the exchange environment, it will react in various ways to examine the signal, such as hunting for stock sold or conducting activities in silent form and waiting for new developments. According to Khaveh et al. (2012) "the main goal of each company is maximizing its shareholders wealth. Potential investor tends to continuous and sustainable profitability, higher profit, and lower risk". Signaling theory in this research is used to explain the effect of Price to Earnings Ratio (PER), world oil price, inflation, exchange rate toward stock prices of the mining sector companies listed in IDX.

\subsection{Price to Earnings Ratio (PER) toward Stock Prices}

Price to Earnings Ratio (PER) is the ratio used to assess stock performance by looking at the low level as a benchmark for purchasing decisions, when compared with other stock prices for a similar industry. According to Sharif et al. (2015), investors believe that a company will have a promising future if it has a high Price to Earnings Ratio (PER). Therefore, a high PER becomes a positive signal that can attract investors to buy stock so that it can affect stock prices (Campello \& Graham, 2013). If PER increases then the stock price will increase (Yumia \& Khairunnisa, 2015). PER is recognized as a good valuation method and covers the entire company including estimating the value or price of the stock. The investors' desire is to analyze stocks through financial ratio such as PER, because there is an investor's desire for a decent outcome from a stock investment and PER is one of the ratios to look at stock price performance. Based on the explanation from the linkage between PER and stock price above, the following hypothesis is proposed:

$\mathrm{H}_{1}$ : Price to Earnings Ratio (PER) has a significant effect on stock prices of mining companies listed in IDX.

\subsection{World Oil Price toward Stock Prices}

The movement of world crude oil prices also affects the movement of the stock price of mining companies. The world oil price used in this research is the price of West Texas Intermediate (WTI) or lightsweet. WTI is a benchmark for world crude oil prices because it has high crude oil quality (United Stated Economy Statistics and Resources, 2018). World oil price is an indicator of the world economy because crude oil is needed for the economic activity. This is because capital market investors consider that increasing of demand indicates the improvement in the global economy after the crisis. According to IMF in Khin and Thambiah (2015), "the high price of crude petroleum oil continued to be an issue of concern all over the world and it had also a major impact on almost all emerging countries." An increasing in world oil demand was followed by increasing demand for mining commodities. Conversely, falling energy prices reflects a weakening of the global economic recovery. Therefore, if oil prices increase, expectations for the improved performance of companies will also increase and automatically the stock price will increase (Jatirosa, 2014; Hasyim \& Jabid, 2019). Based on the explanation from the linkage between world oil price and stock price above, the hypothesis is:

$\mathrm{H}_{2}$ : World Oil Price has a significant effect on stock prices of mining companies listed in IDX.

\subsection{Inflation toward Stock Prices}

Inflation affects the economy through income and changes in production efficiency. The inflation is not in line with the stock price. The price of commodities which tends to increase reflects inflation that has resulted in a decrease in company performance. If the company's production costs increase, the selling price of goods will increase too. The high selling price causes a decrease in the purchasing power of the society. This condition has an impact on the company's profit which will decrease and will cause the 
company's stock price to also decrease. Inflation is closely related to the decline in the purchasing power of individuals and companies. The research of the relationship between inflation and stock prices conducted by Hanafiah et al. (2015) state higher inflation rate reduces the level of profitability of the companies. The fall in corporate profits is bad information for traders on the stock exchange and results in a decrease in the company's stock price. Therefore, the following hypothesis is proposed:

$\mathrm{H}_{3}$ : Inflation has a significant effect on stock prices of mining companies listed in IDX.

\subsection{Exchange Rate toward Stock Prices}

Exchange rate volatility is a real challenge for investors in investing the money in the capital market because the fluctuating exchange rate is a very basic statistics for investors in carrying out the economic activities (Kurniadi, 2013). The depreciated Rupiah exchange rate will result in greater costs to be borne by the company and reduces the level of profitability, especially for companies that rely solely on raw materials from abroad, and will also be able to hit companies that only rely on foreign loans in the form of US dollars to finance their operations. This will reduce the company's stock price traded on the capital market. Fluctuations in the value of the Rupiah towards a stable foreign currency will greatly affect the investment climate in the country, especially the capital market. The appreciation of the Rupiah exchange rate toward the dollar will have an impact on the development of the marketing of Indonesian products abroad, especially in terms of price competition. If this happens, it will indirectly have an effect on the trade balance, because of the decrease in the import value compared with the export value. Furthermore, it will also affect Indonesia's balance of payments, which increases due to greater exports than imports, which in turn has a positive impact on the stock market (Kurniadi, 2013). Based on the explanation from the linkage between exchange rate and stock price above, the following hypothesis is proposed:

$\mathrm{H}_{4}$ : Exchange rate has a significant effect on stock prices of mining companies listed in Indonesia Stock Exchange (IDX).

According to Sekaran and Bougie in Haur et al. (2017) "the research framework describes the relationship among variables rather than describing variables as either cause or effect in which the cause is the independent variable and the direction of the effect". Tham et al. (2017) stated that, "the development of concepts, theories, and conceptual framework is facilitated by a greater focus via focused and selective observation". Based on the linkage of dependent and independent variables has been previously described and it will be tested whether the variable PER, world oil price, inflation, and exchange rate affect the stock price of mining companies listed in the Indonesia Stock Exchange (IDX). The conceptual framework of this research will be depicted in the Fig. 1.

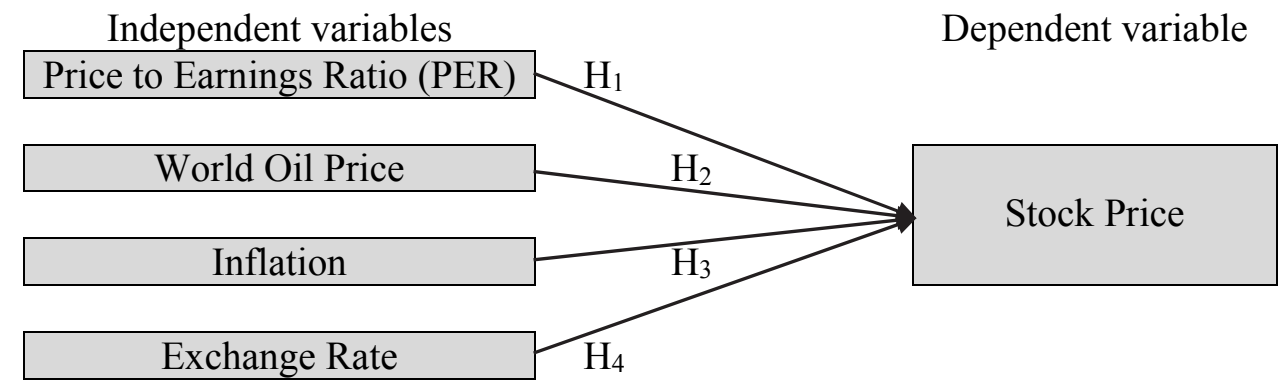

Fig. 1. Conceptual Framework

\section{Research Methodology}

Data used in this research is quantitative data. The population in this research are the mining companies listed in Indonesia Stock Exchange (IDX). There are 48 mining companies listed in Indonesia Stock Exchange. In this study, unit of analysis is organization in the year from 2013 to 2017, used for the research. The object of this research is the mining sector listed in the Indonesian Stock Exchange. This sector was chosen as the object of research because this sector has experienced development and began to show its contribution to the growth of the Indonesian economy lately. This research takes samples by 
using a non-probability sampling technique specifically in purposive sampling technique. Sample criteria used in this research are (1) Mining companies listed in the Indonesia Stock Exchange (IDX) in the period 2013 - 2017 (have audited and published financial statements); (2) There is no delisting during 2013 2017; (3) Companies listing in IDX before 2013. By using purposive sampling method, there are 35 mining companies selected to be analysis. Based on the calculation sampling, the number of mining companies that can be used as sample is 35 companies with the period of 5 years research data, so that in this research there are 175 units (35 companies x 5 years) of analysis. To test the model, this study used the panel data analysis approach, and EVIEWS 10 was used to analyze the data. The panel data or called longitudinal data is a group of individual data that has been examined over a period of time. According to Khin and Thambiah (2014) "the panel data can use to analyze and compare the statistical results from all the models in order to determine the accuracy of which methods were more accurate in terms of statistical criteria". There are several test equipment accomplished in a classic assumption test in this research such as normality test, multicollinearity test, and heteroscedasticity test.

\section{Discussion and Empirical Results}

\subsection{Selection Techniques of Panel Data Regression Estimation}

\subsubsection{Chow Test}

The first test is Chow Test which is used to determine whether a panel data regression technique with a Common method Effect is better than Fixed Effect Model. This test can be selected by looking at the amount of probability-value (p-value) of Cross Section Chi Square. If the p-value Cross Section Chi Square $\geq 0.05$ then $\mathrm{H}_{0}$ is accepted, that is the Common Effect Model (Pool Least Square) that will be selected. The result of the Chow test can be seen in Table 1 below.

Table 1

The results of Chow test

\begin{tabular}{llll}
\hline Effects Test & Statistics & d.f. & Probability \\
\hline Cross-section F & 52.128385 & $(34,136)$ & 0.0000 \\
Cross-section Chi-square & 462.235775 & 34 & 0.0000 \\
\hline
\end{tabular}

Based on the result the p-value Cross-Section Chi Square $=0.0000<0.05$ thus $\mathrm{H}_{0}$ is not accepted and $\mathrm{H}_{1}$ is accepted, that is the Fixed Effect Model that is proper compared to the Common Effect Model to estimate panel data regression.

\subsubsection{Hausman Test}

Hausman test is a statistical test used to select the model or models Fixed Effect and Random Effect Model. According to Abidin and Haseeb (2018) "the Hausman test has recommended that settled impact of Panel analysis is the fitting technique to be received". After knowing the Chow Test and the Fixed Effect Model used, the panel data model must be compared again between Fixed Effect Model and Random Effect Model. If the Chi-Square probability $\geq \alpha(0.05)$, then $\mathrm{H}_{0}$ is accepted, the Random Effect Model will be used.

Table 2

The results of Hausman test

\begin{tabular}{cccc}
\hline Test Summary & Chi-Sq. Statistic & Chi-Sq. d.f. & Prob. \\
\hline Cross-section random & 0.135442 & 4 & 0.9978 \\
\hline
\end{tabular}

Based on the result show that the $p$-value Chi Square $=0.9978>\alpha(0.05)$ thus Random Effect Model that is better than the Fix effect Model to estimate panel data regression. 


\subsubsection{Panel Data Regression}

Panel data regression analysis model in this research uses the Random Effects model. The selection of Random Effects method as a panel data analysis method in this research was previously tested through Chow Test and Hausman Test first, so that, the Random Effect method is the most appropriate to test the panel data in this research. Table 3 shows test results of Panel Data with Random Effect Model.

Table 3

The Results of Panel Data

\begin{tabular}{ll}
\hline Variable & Coefficient \\
\hline C & 6.728931 \\
PER & 0.000496 \\
OIL & 0.009988 \\
INFLATION & -0.131309 \\
EXCHANGE & $-3.46 \mathrm{E}-05$ \\
\hline
\end{tabular}

Thus we have,

STOCK $=6.72893124037+0.00049642853383 \times \mathrm{PER}+0.00998753318871 \times \mathrm{OIL}-$ $0.131309241335 \times$ INFLATION $-3.4627332305 \mathrm{e}-05 \times$ EXCHANGE $+[\mathrm{CX}=\mathrm{R}]$

Coefficient Determination $\left(\mathrm{R}^{2}\right)$ is a measure that shows how much the independent variable contributes to the dependent variable. Table 4 shows the results of coefficient determination test of this research.

Table 4

Coefficient Determination

\begin{tabular}{llll}
\hline \multicolumn{5}{l}{ Weighted Statistics } & & \\
\hline R-squared & 0.150275 & Mean dependent var & 0.861966 \\
Adjusted R-squared & 0.130282 & S.D. dependent var & 0.489831 \\
S.E. of regression & 0.456810 & Sum squared resid & 35.47479 \\
F-statistic & 7.516189 & Durbin-Watson stat & 1.630533 \\
Prob(F-statistic) & 0.000013 & & \\
\hline
\end{tabular}

Based on Table 4 and the equation model, it can be seen that the influence of PER $\left(\mathrm{X}_{1}\right)$, world oil price $\left(\mathrm{X}_{2}\right)$, inflation $\left(\mathrm{X}_{3}\right)$, and exchange rate $\left(\mathrm{X}_{4}\right)$ toward stock price $\left(\mathrm{Y}_{2}\right)$ is 0.1302 (Adjusted R-Square $=$ 0.1302 ). This means that the influence of independent variables toward dependent variable is $13.02 \%$ and the rest is influenced by other variables not included in this research.

\subsubsection{Hypotheses Test}

To know the effect of independent variable on the dependent variable, we have tested hypothesis with $t$ test (partial significance test). The $t$ test is a statistics used to test the influence of independent variable partially to the dependent variable. The result of $t$ test can be seen in Table 5. The value of $t$ table is obtained from the distribution table $\mathrm{t}$ with a significance level of $5 \%(0.05)$ one tail and $\mathrm{df}=170$ for the model equation is $1.9740(\mathrm{df}=\mathrm{n}-\mathrm{k}, \mathrm{n}=$ total sample, $\mathrm{k}=$ total variable $)$.

The results of Table 5 shows that Price to Earnings Ratio (PER), world oil price, and inflation have $t$ count value $>\mathrm{t}$ table value then the hypotheses are accepted. Meanwhile, the exchange rate has $\mathrm{t}$ count value $<\mathrm{t}$ table value then the hypothesis is not accepted. Regression analysis that has been done aims to determine the relationship between variable independent (Price to Earnings Ratio, world oil price, inflation and exchange rate) and variable dependent (stock price). 
Table 5

Hypothesis Test of Partial Test (T-Test) Result

\begin{tabular}{|c|c|c|c|c|}
\hline Hypothesis & $\mathrm{T}$ table & $\mathrm{T}$ count & Sig. Value & Notes \\
\hline $\begin{array}{l}\mathrm{H}_{1} \text { : Price to Earnings Ratio (PER) has a significant on towards } \\
\text { stock prices of mining companies listed in IDX. }\end{array}$ & 1.9740 & 2.0649 & 0.0405 & Accepted \\
\hline $\begin{array}{l}\mathrm{H}_{2} \text { : World Oil Price has a significant on towards stock prices } \\
\text { of mining companies listed in IDX. }\end{array}$ & 1.9740 & 3.2451 & 0.0014 & Accepted \\
\hline $\begin{array}{l}\mathrm{H}_{3} \text { : Inflation has a significant effect on stock prices of min- } \\
\text { ing companies listed in IDX. }\end{array}$ & 1.9740 & 2.6509 & 0.0088 & Accepted \\
\hline $\begin{array}{l}\mathrm{H}_{4} \text { : Exchange rate has a significant on towards stock prices of } \\
\text { mining companies listed in (IDX). }\end{array}$ & 1.9740 & 0.5381 & 0.5981 & Not Accepted \\
\hline
\end{tabular}

The hypothesis testing shows that Price to Earnings Ratio (PER) partially has positive and significant effect on stock price in mining sector companies listed in Indonesia Stock Exchange (IDX) (Campello \& Graham, 2013; Yumia \& Khairunnisa, 2015; Sharif et al., 2015). If PER is increased then the stock price will increase too. Otherwise, if PER is decreased then the stock price will decrease. World oil price has a positive and significant effect on stock price in mining sector companies listed in Indonesia Stock Exchange (IDX) (Gupta, 2016; Pardede et al., 2016; Raza et al., 2016). If world oil price is increased then the stock price will increase. Conversely, if world oil price is decreased then the stock price will also decrease. The increase in world oil prices which was also followed by an increase in the prices of mining products and increased mining prices increased the company's revenue. This phenomenon caused by most of the issuers in the mining sector in Indonesia are companies that are directly related to crude oil commodities. In addition, the sentiment of increasing consumption of petroleum commodities during the research period in Indonesia caused world oil prices to affect the movement of stock prices of mining sector companies. Increased income at companies can move stock prices through positive investor sentiment. Therefore, that the stock price of the mining sector has increased following the increase in world oil prices.

Based on the results of the analysis in this research, it can be seen that inflation has a negative and significant effect on stock price in mining sector companies listed in Indonesia Stock Exchange (IDX) Hanafiah et al. (2015) and Munajat and Aisyah (2017). The negative correlation between inflation and stock prices is caused by inflation that occurs based on cost-push inflation, namely inflation that occurs because of an increase in production costs. With the increase in prices of raw materials and labor, while the economy is in a state of inflation, producers do not have the courage to increase the price of the products. Its effect, the company's profits to pay dividends will decrease which would have an impact on the valuation of negative stock prices, so investors' interest in investing in stocks will decrease. Therefore, investors use inflation as a benchmark to compare returns on stock prices when investing.

Exchange rate partially has negative and insignificant effect on stock price in mining sector companies listed in Indonesia Stock Exchange (IDX) (Anisa \& Darmawan, 2018; Hanafiah et al., 2015). Changes in the exchange rate of the Rupiah against the dollar each year during the study period (2013-2017) only ranged from Rp. 1000 - Rp. 3000. Changes in the exchange rate which are still classified as not too large so as not to have a significant effect on the capital market in Indonesia. Then can be concluded that there is the positively significant influence of Price to Earnings Ratio (PER) and world oil price partially on stock prices of mining sector companies listed in IDX. Moreover, inflation has a negative and significant effect on stock prices of mining sector companies listed in IDX.

\section{Conclusion}

Based on the research conducted in mining companies listed in Indonesia Stock Exchange (IDX), there are several things that can be concluded. The results confirm the effects of PER, world oil price, inflation, exchange rate on the stock price in mining companies listed in Indonesia Stock Exchange (IDX). It can be concluded that world oil price influence partially on stock prices of mining sector companies listed in 
IDX and inflation negatively influenced stock prices. Finally, the exchange rate has maintained a negative influence but insignificant on stock price of mining sector companies listed in IDX.

\subsection{Implication}

In terms of theoretical implication, the results of this research will add value to the knowledge and understanding the factors affecting stock prices in mining sector companies listed in Indonesia Stock Exchange during the period 2013-2017. The results of this research are believed to be important and useful for investment in mining companies in Indonesia. The benefits of correct decision making will benefit the companies such as obtaining large capital that can develop the company, reducing the dependence of company to debt on the bank, and increase the solvency of the company so that it improves the value and trust of the company. For investors, decision making is a process of selecting the best alternative from a number of alternatives available under the influence of complex situations. The benefits of correct decision making will benefit investors such as obtaining maximum results and profits, minimize risk, etc. in accordance with economic growth, and expand business networks. For further researchers, we hope that this research could contribute for the development of financial accounting and capital market theories related to the importance of the factors that influence stock prices in making investment decisions in the stock market.

\subsection{Recommendation}

This research is important and useful for the managerial sector of mining companies in Indonesia. Both in terms of companies and investor. For further researchers, researchers who will examine the same topic with this research can deepen research so that more understanding of this topic will be gained. Furthermore, the results of this study and other future studies are expected to be able to help stakeholders.

\subsection{Limitation}

This research has several limitations. The first limitation comes from resources, such as costs, time, and energy. The second limitation is about variables, because of the limited time in research, the variables are only collections of variables that had the most influence on stock prices based on the previous studies. This research only uses 3 macroeconomics factors, although there are still other factors that are probably important effect on stock prices. In addition, this research only chooses the mining sector, the other researchers should examine another sectors to obtain maximum result and recommendation. However, certain limitations also accrue from this research.

\section{Acknowledgement}

The authors would like to thank the anonymous referees for constructive comments on earlier version of this paper.

\section{References}

Abidin, I. S. Z., \& Haseeb, M. (2018). Malaysia-Gcc bilateral trade, macroeconomic indicators and Islamic finance linkages: A gravity model approach. Academy of Accounting and Financial Studies Journal, 22, 1-7.

Ahmed, S., \& Giafri R.N.M. (2015). The role of double taxation treaties on attracting foreign direct investment: A review of literature. Research Journal of Finance and Accounting, 6(12).

Anisa, I., \& Darmawan, A. (2018). Pengaruh Ekonomi Makro Dan Harga Komoditas Tambang Dunia Terhadap Indeks Harga Saham Sektor Pertambangan Di Indonesia. Jurnal Administrasi Bisnis, 56(1).

Bank Indonesia. (2018). Monetary-Exchange Rates. Available online at www.bi.go.id

Bank Indonesia. (2018). Inflation. Available online at www.bi.go.id

Campello, M., \& Graham, J. R. (2013). Do stock prices influence corporate decisions? Evidence from the technology bubble. Journal of Financial Economics, 107(1), 89-110. 
Energy Information Administration (EIA). 2018. Petroleum Status Report. Available Online at https://www.eia.gov

Fahmi, I. (2015). Pengantar Pasar Modal. $3^{\text {rd }}$ Edition. Bandung:Alfabeta

Gupta, K. (2016). Oil price shocks, competition, and oil \& gas stock returns-Global evidence. Energy Economics, 57, 140-153.

Hanafiah, M.S., Sudjana, N., \& Sulasmiyati, S. (2015). Pengaruh Harga Minyak Dunia, Nilai Tukar Rupiah terhadap dollar, dan Tingkat Inflasi terhadap Harga Saham-Studi pada PT Bumi Resources Minerals Tbk Periode Januari 2008-2013. Journal of Administration Business, 28(2), 1-7.

Hasyim, A \& Jabid, A. (2019). Does cost accounting system contributes in supply chain operations?. Uncertain Supply Chain Management, 7(2), 157-168.

Haur, F.C., Khatibi, A., \& Azam, S.M.F. (2017). Antecedents of consumers' perception towards online advertising in Malaysia: The structure equation modeling approach. European Journal of Management and Marketing Studies, 2(3), 15-30

Indonesia Investment Coordinating Board. (2018). Statistics of Domestic Direct Investment Realization. Available online at www.bkpm.go.id

Indonesia Investment Coordinating Board. (2018). Statistics of Foreign Direct Investment Realization. Available online at www.bkpm.go.id

Indonesia Stock Exchange (2013). Annual Report. Available at www.idx.co.id/en-us Indonesia Stock Exchange (2014). Annual Report. Available at www.idx.co.id/en-us Indonesia Stock Exchange (2015). Annual Report. Available at www.idx.co.id/en-us Indonesia Stock Exchange (2016). Annual Report. Available at www.idx.co.id/en-us Indonesia Stock Exchange (2017). Annual Report. Available at www.idx.co.id/en-us Jatirosa, S.A. (2014). Analisis Pengaruh Harga Minyak Dunia, Tingkat Suku Bunga SBI, Kurs Rupiah/US\$ Terhadap Return Saham Sektor Pertambangan yang Tercatat di Bursa Efek Indonesia Periode 2003-2013. Journal of Economics and Business, 43587 (http://eprints.undip.ac.id/43587/)

Khaveh, A., Nikhashemi, S. R., Yousefi, A., Haque, A. (2012). Environmental and Social Performance Disclosure and Shareholder's Wealth-A Perspective from Malaysian Companies. Australian Journal of Business and Management Research, 1(12), 33-41.

Khin, A. A., \& Thambiah, S. (2014). Forecasting analysis of price behavior: A case of Malaysian natural rubber market. American-Eurasian Journal of Agricultural \& Environmental Sciences, 14(11), 1187 1195.

Khin, A. A., \& Thambiah, S. (2015). An Illustration of Modelling Process of VECM Model for Rubber Industry in Malaysia: A Conceptual Framework. International Conference on Business and Economics Research, 978-967-5705-11-3 (http://internationalconference.com.my)

Kurniadi, R. (2013). Analisis Pengaruh Nilai Tukar, Suku Bunga (SBI) dan Jumlah Uang Beredar (JUB) terhadap Nilai Harga Saham Sektor Properti di Bursa Efek Indonesia (BEI) Periode 200-2011. Thesis. Faculty of Economic and Business. UIN Syarif Hidayatullah Jakarta.

Munajat, F., \& Aisyah, I.S. (2017). Pengaruh Tingkat Suku Bunga, Nilai Tukar, Inflasi, dan Pertumbuhan Laba terhadap Harga Saham (Studi pada Perusahaan Sektor Pertambangan Sub Sektor Batubara yang Terdaftar di Bursa Efek Indonesia periode 2011-2015). Thesis. Faculty of Economic and Business. Pasundan University.

Pardede, N., Hidayat, R. R., \& Sulasmiyati, S. (2016). Pengaruh Harga Minyak Mentah Dunia, Inflasi, Suku Bunga (Central Bank Rate), Dan Nilai Tukar (Kurs) Terhadap Indeks Harga Saham Sektor Pertambangan Di ASEAN (Studi Pada Indonesia, Singapura, Dan Thailand Periode Juli 2013-Desember 2015). Jurnal Administrasi Bisnis, 39(1), 130-138.

Pertiwi, T., Yuniningsih, Y \& Anwar, M. (2019). The biased factors of investor's behavior in stock exchange trading. Management Science Letters, 9(6), 835-842.

Raza, N., Shahzad, S. J. H., Tiwari, A. K., \& Shahbaz, M. (2016). Asymmetric impact of gold, oil prices and their volatilities on stock prices of emerging markets. Resources Policy, 49, 290-301.

Sari, E. L., \& Wijayanto, A. (2015). Pengaruh Keputusan Investasi, Pendanaan dan Dividen terhadap Nilai Perusahaan dengan Risiko sebagai Variabel Mediasi. Management Analysis Journal, 4(4), 281291. 
Sekaran, U., \& Bougie, R. (2016). Research methods for business: A skill building approach. John Wiley \& Sons.

Sharif, T., Purohit, H., \& Pillai, R. (2015). Analysis of factors affecting share prices: The case of Bahrain stock exchange. International Journal of Economics and Finance, 7(3), 207-216.

Tham, J., Ab Yazid, M. S., Khatibi, A. A., \& Azam, S. F. (2017). Internet and data security-understanding customer perception on trusting virtual banking security in Malaysia. European Journal of Social Sciences Studies, 7(2), 186-206.

Yumia, M. \& Khairunnisa. (2015). The influence of Return on Equity (ROE), Earning per Share (EPS), and Price to Earnings Ratio (PER) to stock price-Case study on metal and minerals mining company in 2010-2014. E-Proceeding of Management, 2(3).

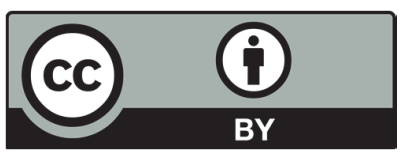

(C) 2019 by the authors; licensee Growing Science, Canada. This is an open access article distributed under the terms and conditions of the Creative Commons Attribution (CCBY) license (http://creativecommons.org/licenses/by/4.0/). 